\title{
Tracing our ruin and folly in the AIDS epidemic
}

\author{
Dark Star Requiem \\ Jill Battson \\ Folded \& Gathered; 2010.
}

$\mathrm{W}$ hat would an innovation of the emotions feel like? In this slim, matte-black volume of wide emotion, the history of the HIV/AIDS disaster is chronicled in a sequence of poems that is also a libretto.

Originally commissioned by Luminato, the Toronto Festival of Arts \& Creativity, Dark Star Requiem premiered in June 2010 in Toronto, Ontario when Jill Battson's poems were accompanied by a piano trio, two percussionists, four soloists and a choir.

In book form, the work is accompanied by a moving personal statement by the HIV/AIDS activist, Louise Binder, who worked with HIV positive women infected during the genocide in Rwanda, and after. "Their courage and hope astounded me."

In an introduction, Battson tells how the project developed. First, in 2005, in collaboration with the composer Andrew Staniland, she wrote a chamber opera about a resurgence of HIV/AIDS. That earlier work was titled Ashlike on the Cradle of the Wind.

These poems use a language that is accessible, solid, generous, and stark. They trace our ruin and folly from ill chimpanzees in the Congo, through the voices of men and women, gay or not, both dead and surviving. They seem to loom out of darkness, each with an aspect of the full story to share:

The waiting room has the odor of well-thumbed magazines old newsprint and cold ink, the soft damp pages

...

I've been a wreck these past two weeks with the need to know ...

the nurse brings her verdict.

To hear these poems sung by a twenty-voice choir must be devastating. Even in print, the slow increase of human suffering, the harsh music of that anguish, comes through.

The clarity of the narrative is interspersed with Latin phrases, African words, street slang, medical terminology and the names of pharmaceuticals.

Even in simply reading a poem called "Cocktail" that does no less than list alphabetically the ingredients of one concoction, we are taken inside the reality of hope and despair.

Or consider some "Malawian/ Chewa words and their meanings":

\section{kukhazikitsa ananfedwa: providing the bereaved with company and assistance amayi amafungatira bwino maliro: women know how to best take care of a dead body}

These truths are not told as a simplified melodrama, and Battson is smart to let the details (and the jargon) spell the horror for us. The rhythms she adopts are long and ominous. The virus itself is animated: you are the black lion, padding unheeded among folktales and caution.

Near the end of the book, African women tell burial stories. One of the last poems is called "Funeral Trees - Praise Poem." We are surprised to arrive at praise. We are brought to an encompassing image of "green shelters for the dead and living!"

Finally, there is the havoc of a number: "twenty-five million."

Here is a book that has gone largely unnoticed in literary circles. It has had a job to do with others, has had its dark music performed in the dark, and has moved many.

This is not experimental writing; though I have suggested ways in which it pushes language to the forefront. It is flauntingly lyrical.

What would an innovation of the emotions feel like? What would it sound like?

It would be wider than charity. It would not be composed of one voice but many. It would not be ironic.

It would feel and sound like this.

\section{Phil Hall}

Poet

Otty Lake, Ont.

Phil Hall's latest book of essay-poems, Killdeer (BookThug; 2011), was awarded the 2011 Governor General's Literary Award for Poetry. 